\title{
Calcium release from milk concentrated by ultrafiltration and diafiltration
}

\author{
Y. Li and M. Corredig ${ }^{1}$ \\ Department of Food Science, University of Guelph, Guelph, Ontario, Canada, N1H2W1
}

\begin{abstract}
The present work studied the solubilization of $\mathrm{Ca}$ during acidification in milk concentrated by ultrafiltration (UF) and diafiltration (DF). The effect of heating milk at $80^{\circ} \mathrm{C}$ for 15 min was also evaluated. In addition to measuring buffering capacity, the amount of $\mathrm{Ca}$ released as a function of $\mathrm{pH}$ was determined. The area of the maximum peak in buffering capacity observed at $\mathrm{pH} \sim 5.1$, related to the presence of colloidal Ca phosphate, was significantly affected by casein volume fraction but did not increase proportionally with casein concentration. In addition, a lower buffering capacity and less solubilized $\mathrm{Ca}$ were measured in $2 \times \mathrm{DF}$ milk compared with $2 \times$ UF milk. Heat treatment did not change the buffering capacity or Ca release in $1 \times$ and $2 \times$ concentrated milk. On the other hand, at a higher volume fraction $(4 \times)$, more Ca was present in the soluble phase in heated $4 \times \mathrm{UF}$ and DF milk compared with unheated milk. This is the first comprehensive study on the effect of concentration, distinguishing the effect of UF from that of DF, before and after heating, on Ca solubilization.
\end{abstract}

Key words: casein micelle, concentrated milk, buffering capacity, calcium release, acidification

\section{INTRODUCTION}

Skim milk is a colloidal suspension of casein micelles and whey proteins, and it contains calcium, magnesium, potassium, and zinc, as well as chloride, phosphate, and citrate anions (Holt, 2004). Calcium and phosphate are present in colloidal form in the casein micelles, associated with phosphoserine amino acid (Holt, 2004). Colloidal calcium phosphate (CCP) is composed of amorphous hydrated $\mathrm{CaHPO}_{4} \cdot 2 \mathrm{H}_{2} \mathrm{O}$ distributed throughout the micelle as nanoclusters of a few nanometers in size (Holt et al., 1998; Marchin et al., 2007). Colloidal calcium phosphate plays an important role in the stability of the casein micelles and it is in equilibrium with the Ca present in the serum phase (Holt, 2004). The concentration of total $\mathrm{Ca}$ in

Received October 5, 2013.

Accepted February 21, 2014.

${ }^{1}$ Corresponding author: milena.corredig@uoguelph.ca milk is approximately $1200 \mathrm{mg} / \mathrm{L}$, of which $400 \mathrm{mg} / \mathrm{L}$ is in soluble form and $800 \mathrm{mg} / \mathrm{L}$ in insoluble form, at the natural pH of milk (Le Graët and Gaucheron, 1999; Rahimi-Yazdi et al., 2010).

The distribution and equilibrium state of $\mathrm{Ca}$ are affected by environmental conditions such as $\mathrm{pH}$ or temperature, altering the processing characteristics of milk (Law and Leaver, 1998; Le Graët and Gaucheron, 1999). For example, when milk is stored at $4^{\circ} \mathrm{C}, \mathrm{CCP}$ is released from casein micelles, along with $\beta$-casein, because of reduced hydrophobic interactions. These changes are reversible once the milk is rewarmed to room temperature (Downey and Murphy, 1970; Pierre and Brule, 1981). On the other hand, extensive heat treatment (e.g., $>90^{\circ} \mathrm{C}$ for several minutes) results in a decrease of soluble $\mathrm{Ca}$, a transfer of the soluble $\mathrm{Ca}$ to the colloidal phase, and a concomitant decrease in milk pH (Rose and Tessier, 1959; Pouliot et al., 1989).

The equilibrium between colloidal and soluble $\mathrm{Ca}$ is dependent on pH (Law and Leaver, 1998; Le Graët and Gaucheron, 1999). At pH around the isoelectric point of casein, the $\kappa$-casein layer on the surface of the protein particles collapses and solubilization of CCP occurs, especially between $\mathrm{pH} 5.5$ and 5.0, with solubilization of caseins depending on temperature (Dalgleish and Law, 1988; Dalgleish et al., 2005). The solubilization of $\mathrm{Ca}$ is complete around pH 5.0 (Le Graët and Gaucheron, 1999), with maximum buffering capacity at pH 5.1 (Lucey et al., 1996; Salaün et al., 2005).

Although the effect of $\mathrm{pH}$ on casein micelle structure and their release of Ca into skim milk is at least partly understood, much less is known about the changes occurring in milk that has been concentrated by UF and diafiltration (DF). When water is removed and the concentration of total solids in skim milk increased, the decreased distance between casein micelles forces them to interact more frequently with each other (DeKruif, 1998). In addition, with concentration, the total balance of soluble and sedimentable Ca changes, resulting in a considerable proportion of soluble $\mathrm{Ca}$ and phosphate being transferred between soluble and colloidal states (Hardy et al., 1984). Although some work has been published on the effect of concentration on $\mathrm{Ca}$ release during acidification, most research to date has been carried out on reconstituted milk powder or milk 
concentrates (Lucey et al., 1996; Le Graët and Gaucheron, 1999); therefore, a comprehensive look at the effect of UF and DF concentration is needed.

Concentration of skim milk by UF changes the composition of the milk by increasing the proteins and colloidal minerals in the retentate and decreasing the water, soluble minerals, lactose, and nonprotein nitrogen, which are transmitted through the membrane and maintained in the permeate (Mistry and Maubois, 2004). Recent studies have suggested that the renneting functionality and physical properties of casein micelles are affected when concentrating milk protein by UF, especially at high volume reductions (Ferrer et al., 2011). Moreover, DF, the process of adding water to the concentrated retentate, while enhancing the levels of concentration in the retentate, may further affect the integrity of the casein micelles and the release of $\mathrm{Ca}$. Earlier studies have shown that dialysis of milk against water (i.e., a change in the ionic composition of the serum phase), while removing free $\mathrm{Ca}$ and other ions from the serum phase, causes dissociation of caseins due to the loss of CCP (Davies and White, 1960; McSweeney and Fox, 2009).

The present research focused not only on the effect of the concentration (i.e., increase in the volume fraction of the casein micelles) but also DF (i.e., the addition of water and mineral imbalance created in the serum phase) on the buffering capacity and Ca retention of the casein micelles. We hypothesized that although the concentration of $\mathrm{Ca}$ in the colloidal phase increases with the volume fraction of casein micelles, this increase does not affect the release rate of $\mathrm{Ca}$ in the soluble phase. The mode of concentration (UF or UF plus DF) as well as heating was tested to determine if processing history affects the release of the Ca.

\section{MATERIALS AND METHODS}

\section{Sample Preparation}

Fresh, pasteurized skim milk (Crown Dairy Ltd., Guelph, ON, Canada) was concentrated using a tangential flow filtration system (Purosep LT-2, SmartFlow Technologies, Apex, NC), using a Optisep 3000 polyethersulfone (PES) membrane module (nominal molecular weight cutoff of $10 \mathrm{kDa}$; membrane area of $0.18 \mathrm{~m}^{2} ; 0.75-\mathrm{mm}$ channel height; SmartFlow Technologies). Ultrafiltration was performed at $40^{\circ} \mathrm{C}$ with a transmembrane pressure of $170 \mathrm{kPa}$, recirculating the skim milk to the feed tank at a cross-flow velocity of $12 \mathrm{~L} / \mathrm{min}$. The concentration was determined based on volume reduction, by measuring the amount of permeate. Control milk $(1 \times)$ and UF milks with volume concentration ratios of $2 \times$ and $4 \times$ were obtained.
Diafiltration was carried out by adding Milli-Q water (Millipore Corp., Bedford, MA; twice the retentate volume) to the milk concentrated by UF. Filtration was then continued, under the same conditions as above, until the volume of permeate collected corresponded to the amount of water originally added. The resulting retentates were named $2 \times$ and $4 \times \mathrm{DF}$, to distinguish them from the $2 \times$ and $4 \times$ UF treatments. Sodium azide $(0.02 \% \mathrm{wt} / \mathrm{vol})$ was added to all the milk samples to prevent microbial growth immediately after concentration.

The $1 \times$ (control) and $2 \times$ and $4 \times \mathrm{UF}$ and DF milks (in aliquots of $15 \mathrm{~mL}$ ) were placed in capped glass vials in a water bath at $80^{\circ} \mathrm{C}$ and heated for $15 \mathrm{~min}$, with an additional initial 2 min for the samples to reach the final temperature. This temperature-time combination was used to ensure denaturation of the whey proteins, and it is often used to study the effect of heating on acid-induced gelation of milk (e.g., Guyomarc'h et al., 2003). After heat treatment, the milk samples were immediately cooled to room temperature by immersion in an ice bath, and were stored for at least $1 \mathrm{~h}$ at ambient temperature before any further analyses.

\section{Separation of the Nonsedimentable Fraction}

To investigate the effect of different treatments of milk on the formation of soluble complexes of casein and serum protein, samples were centrifuged at 25,000 $\times g$ for $1 \mathrm{~h}$ at $20^{\circ} \mathrm{C}$ in a Beckman Coulter Optima LE-80K ultracentrifuge, with rotor type $70.1 \mathrm{Ti}$ (Beckman Coulter Canada Inc., Mississauga, ON, Canada). The supernatants were removed from each centrifuge tube with a syringe and filtered using a $0.45-\mu \mathrm{m}$ filter (Millipore Corp., Bedford, MA). The total protein concentration of milk samples and supernatants was measured using a combustion method (Dumas, Leco FP-528; Leco Corp., St. Joseph, MI) using a conversion factor of 6.38. A colorimetric assay (DC assay, Bio-Rad, Mississauga, ON, Canada) was also used to measure protein concentration.

\section{Buffering Capacity}

Acid-base titrations were performed as previously published (Lucey et al., 1996) with minor modifications. The samples $(50 \mathrm{~mL})$ were titrated at $25^{\circ} \mathrm{C}$ from initial $\mathrm{pH}$ to $\mathrm{pH} 2.0$ with $0.1 \mathrm{M} \mathrm{HCl}$ and back-titrated to $\mathrm{pH} 11.0$ with $0.1 \mathrm{M} \mathrm{NaOH}$, added in $0.2 \mathrm{~mL} / \mathrm{min}$. The $d \mathrm{~B}$ (acid or base): $d \mathrm{pH}$ ratios were calculated according to the literature (Salaün et al., 2005). Buffering curves were prepared by plotting the calculated indices as a function of $\mathrm{pH}$ and the peak areas were calculated by the software of OriginPro 8 (OriginLab Corp., Northampton, MA). 


\section{Calcium Determination by Ion Chromatography}

The amount of $\mathrm{Ca}$ in all fractions (centrifugal supernatants and retentates) was measured by nonsuppressed ion chromatography (Rahimi-Yazdi et al., 2010). The amount of Ca present in the serum after centrifugation was measured by mixing $1 \mathrm{~mL}$ of centrifugal supernatant with $200 \mu \mathrm{L}$ of $1 \mathrm{M} \mathrm{HCl}$ and adjusting to a volume of $100 \mathrm{~mL}$ with HPLC water. For the determination of total $\mathrm{Ca}, 666 \mu \mathrm{L}$ of milk or retentate, $400 \mu \mathrm{L}$ of $1 M$ $\mathrm{HCl}$, and $266 \mu \mathrm{L}$ of HPLC water were mixed in a 1.5$\mathrm{mL}$ Eppendorf microcentrifuge tube. The samples were centrifuged at room temperature for $15 \mathrm{~min}$ at 4,500 $\times g$ (Brinkmann Instruments Ltd., Mississauga, ON, Canada) to precipitate the proteins. The supernatant $(1.333 \mathrm{~mL})$ was then diluted to $100 \mathrm{~mL}$ with HPLC water. Samples were analyzed within $48 \mathrm{~h}$.

Chromatography was carried out using an 861 Advanced Compact IC ion chromatograph (Metrohm Ltd., Herisau, Switzerland), consisting of an injection valve, a high-pressure pump, and a conductivity detector. Samples were eluted at $0.9 \mathrm{~mL} / \mathrm{min}$ isocratically with a mobile phase consisting of $1.7 \mathrm{~m} M$ nitric acid and $1 \mathrm{~m} M$ pyridine-2,6-dicarboxylic acid in an 838 sample processor. To accept cations from the sample solution, the 833 IC Liquid Handling Dialysis Unit pumped a $2 \mathrm{~m} M$ nitric acid solution through one side of the dialysis cell while the other side of the cell was fed with the sample. The nitric acid solution $(20 \mu \mathrm{L})$ containing the sample cation was then injected in the column (Metrosep C2-150, Metrohm). Both column and detector temperatures were kept at $30^{\circ} \mathrm{C}$. Calcium standard solutions ( 1 to $10 \mathrm{mg} / \mathrm{L}$ ) were prepared from $1 \mathrm{~g} / \mathrm{L}$ concentrated standards (TraceCERT, Fluka, Sigma, Steinheim, Germany). The amount of insoluble $\mathrm{Ca}$ in milk was calculated as the difference between the total amount of $\mathrm{Ca}$ and that measured in the centrifugal supernatant fractions.

\section{Calcium Release During Acidification}

To investigate the Ca dissociated from casein micelles as a function of $\mathrm{pH}$, different amounts of glucono- $\delta$ lactone (GDL), ranging from 1 to $1.3 \%$ (wt/wt), were added to milk samples. After incubation of the samples at $40^{\circ} \mathrm{C}$ for $4 \mathrm{~h}$, the values of $\mathrm{pH}$ were measured using an AR $15 \mathrm{pH}$ meter (Fisher Scientific, Mississauga, ON, Canada). Samples were then immediately centrifuged at $25,000 \times g$ for $1 \mathrm{~h}$ at $20^{\circ} \mathrm{C}$ and the Ca was measured by chromatography. To obtain similar acidification conditions, different GDL concentrations (1.3, 1.8, and $3.0 \% \mathrm{wt} / \mathrm{wt}$ ) were used for $1 \times$ (control), $2 \times \mathrm{UF} / \mathrm{DF}$, and $4 \times \mathrm{UF} / \mathrm{DF}$ milk samples, respectively.

\section{Statistical Analysis}

All experiments were carried out in triplicate (i.e., 3 separate milk batches and concentrations by filtration), and means and standard deviations are reported. Profiles described below are the averages of those obtained from 3 experiments. Statistical significances were evaluated using ANOVA at $P<0.05$; the mean values were compared using a Tukey test, and all statistic data were processed using $\mathrm{R}$ software ( $\mathrm{R}$ Development Core Team, Vienna, Austria).

\section{RESULTS AND DISCUSSION}

\section{Buffering Capacity}

Milk contains many constituents, including salts, organic acids, and proteins, all of which contribute to its buffering capacity (Lucey et al., 1993a; Salaün et al., 2005). To measure the buffering capacity in milk, the samples were titrated from the initial $\mathrm{pH}$ (approximately 6.7) to $\mathrm{pH} 2.0$ with $0.1 \mathrm{M} \mathrm{HCl}$ and then back-titrated to $\mathrm{pH} 11.0$ with $0.1 \mathrm{M} \mathrm{NaOH}$, as shown in Figure 1.

Buffering curves for $1 \times$ skim milk were similar to those reported in the literature (Lucey and Fox, 1993; Salaün et al., 2005). When milk was titrated with acid from natural $\mathrm{pH}$ to $\mathrm{pH} 2.0$ (Figure 1A), the buffering curve showed a peak at about $\mathrm{pH} 5.1$. At $\mathrm{pH}$ between 3 and 4, the acidic amino acids present in milk proteins (caseins and whey proteins) were then titrated. At $\mathrm{pH}$ around 5.1, the "free" inorganic and organic phosphates associate with $\mathrm{H}^{+}$; this buffering peak has been attributed to solubilized CCP and the formation of free phosphoserine residues (Salaün et al., 2005). This peak was expected to grow with a higher volume fraction of caseins in the $2 \times$ and $4 \times \mathrm{UF}$ and DF retentates.

Figure $1 \mathrm{~B}$ shows the subsequent alkalinization. After a wide peak for the acidic amino acids, the curves showed a peak at about $\mathrm{pH} 6$, attributed to the precipitation of Ca phosphate due to neutralization of $\mathrm{HPO}_{4}{ }^{2-}$ and $\mathrm{H}_{2} \mathrm{PO}_{4}^{-}$(Lucey and Fox, 1993; Lucey et al., 1993b, 1996). With a further increase in $\mathrm{pH}$, another steep increase in buffering capacity was measured above $\mathrm{pH}$ 9 , associated with the presence of basic amino acids and possibly carbonate ions (Salaün et al., 2005).

The changes in the buffering peaks at $\mathrm{pH} 5.1$ and 6.0 in milk concentrated by UF and DF were evaluated to determine possible differences in the amount of colloidal $\mathrm{Ca}$ and phosphate present in the casein micelles. The changes in peak areas for the $\mathrm{pH} 5.1$ and $\mathrm{pH} 6$ peaks are shown in Figure $1 \mathrm{C}$ and 1D, respectively. Figure 1 shows the changes in buffering capacity for 

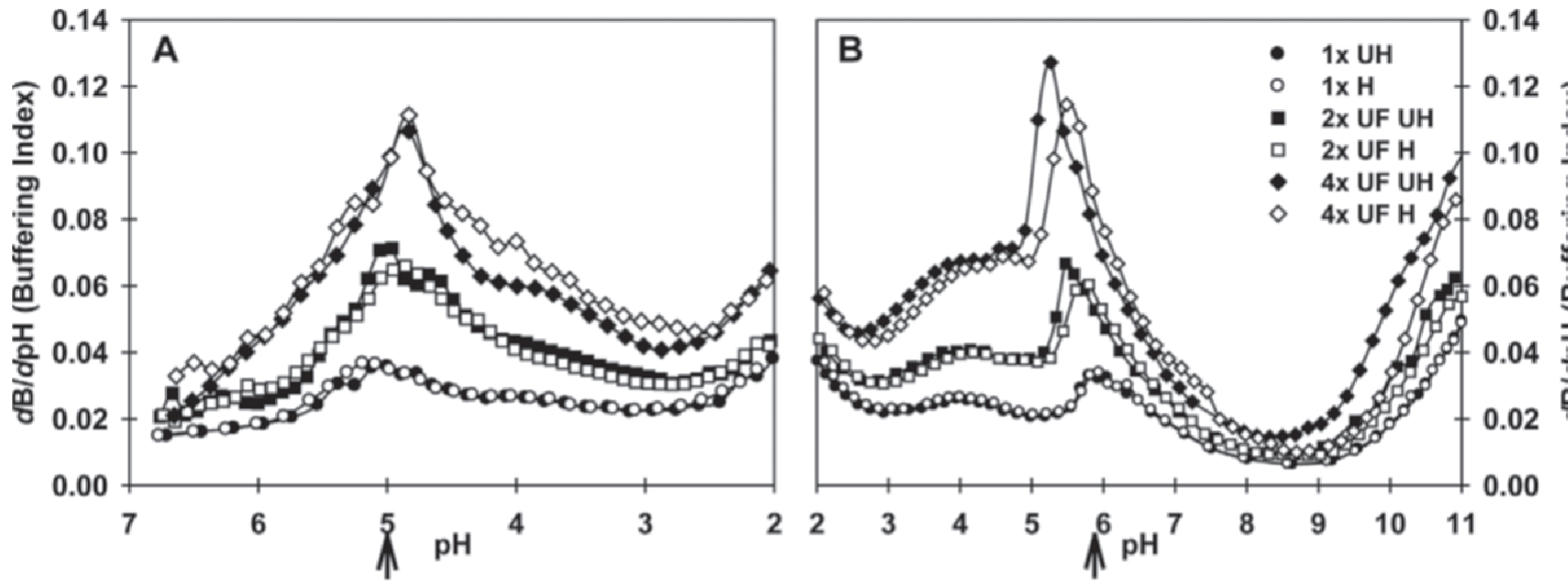

0.14
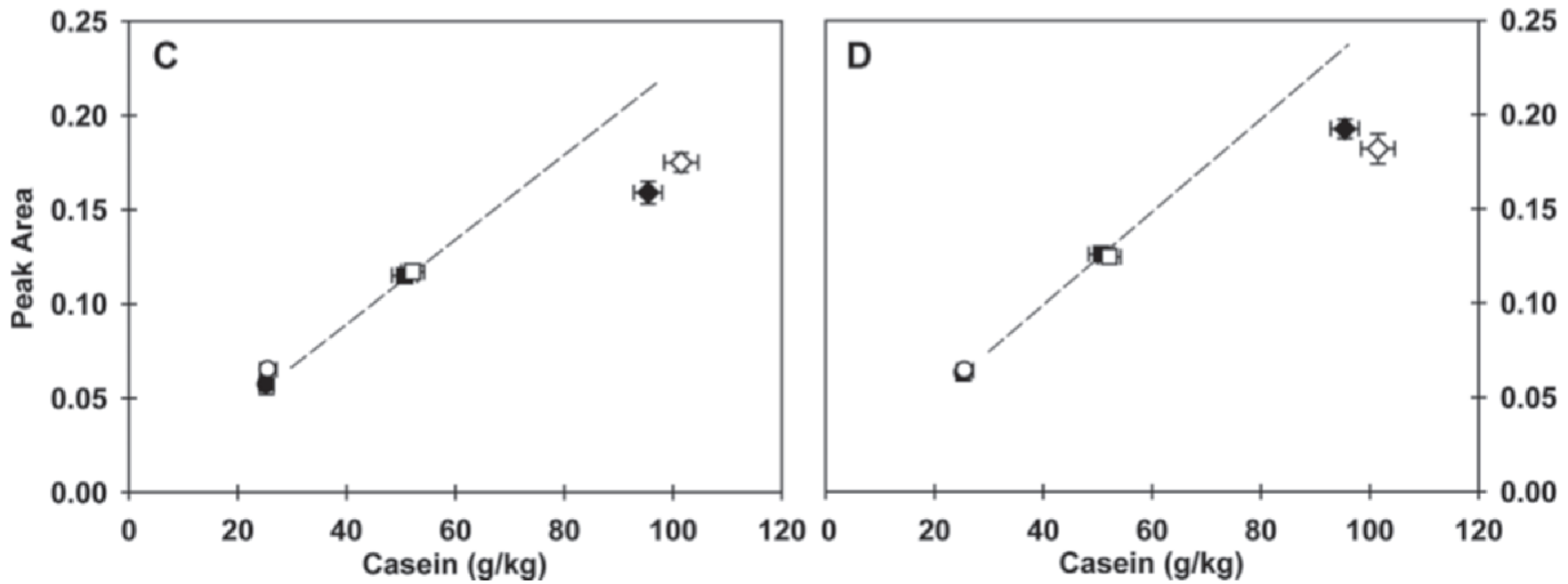

0.25

0.20

0.15

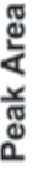

Figure 1. Buffering curves $[d \mathrm{~B}$ (acid or base) $/ d \mathrm{pH}]$ of milk samples, $1 \times$ control (circles), $2 \times$ UF (squares), $4 \times$ UF (diamonds), unheated (UH; filled) and heated (H; empty), acidified from the initial $\mathrm{pH}$ to 2.0 with $\mathrm{HCl}(\mathrm{A})$ and then back-titrated to $\mathrm{pH} 11.0$ with $\mathrm{NaOH}$ (B). The areas of the peaks (see arrows) related to colloidal Ca phosphate are also plotted as a function of casein concentration, for acidification (peak at $\mathrm{pH}$ 5.1) (C) and back titration (peak at $\mathrm{pH}$ around 6) (D). Curves are representative of 3 separate replicate experiments. Error bars represent standard deviations, and lines are drawn to guide the eye and indicate linear increase.

control milk, as well as milk concentrated $2 \times$ and $4 \times$ by UF and DF, before and after heating. We hypothesized that if DF did not cause a significant change in the CCP distribution in the casein micelles, UF and DF milk with similar volume fractions would show similar buffering capacity curves. Any changes in the Ca and phosphate equilibrium with heating treatment may show a change in the buffering capacity of milk.

All samples showed behavior similar to that of skim milk; however, we observed a statistically significant shift in the maximum of the acidification peak from $\mathrm{pH} 5.1$ to 4.8 for the $4 \times$ UF milk compared with control skim milk. This result is consistent with previous reports on the effect of $\mathrm{Ca}$ and phosphate release in concentrated milk: it is necessary to decrease the $\mathrm{pH}$ to a lower value to induce solubilization of colloidal Ca in concentrated milk (Le Graët and Gaucheron, 1999).

The results for $2 \times$ and $4 \times$ milk concentrates were in agreement with a previous study on the buffering capacity of a $5 \times$ UF-concentrated milk (Srilaorkul et al., 1989), and the buffering capacity peaks were higher as a function of concentration, because of the higher protein content compared with that of skim milk. The alkalization curves (Figure 1B) showed similar trends as those shown for acidification, with a shift of buffering capacity at pH 6 to earlier $\mathrm{pH}$ values in the $4 \times$ concentrated milk samples and a greater area for higher milk concentration.

To further investigate the changes in buffering capacity as a function of casein concentration (as CCP 
is related to the concentration of micellar casein), the areas for the 2 peaks related to the presence of CCP in milk were quantified, as shown in Figures 1C and 1D. Although it is known that whey proteins also contribute to the buffering capacity of milk, their change was not considered as important as that of the caseins in comparing between treatments. We found a clear relationship between the total peak area in the buffering capacity experiments and the concentration of caseins. The peak area for the buffering peak at $\mathrm{pH} 5.1$ during acidification and at $\mathrm{pH} 6$ during alkalization in $2 \times$ concentrated milk was proportional to the concentration; that is, lower than expected, in full agreement with the literature (Brule et al., 1974; Mistry and Kosikowski, 1985; St-Gelais et al., 1992). However, in the case of $4 \times$ UF milk (both heated and unheated), the area was lower than expected. These results could be explained by a change in the proportion of casein to colloidal $\mathrm{Ca}$ and phosphate during concentration by UF, even without DF, confirming previous observations (Ferrer et al., 2011).

Figure 1 also depicts the buffering capacity of the same concentrates after heating. It has been reported that changes of buffering capacity can be affected not only by milk composition but also by heat treatment (Lucey et al., 1993a; Salaün et al., 2005). In this work, we observed no statistically significant changes in the peak $\mathrm{pH}$ with heating. The discrepancy may derive from the differences in the heat treatment condition between the studies, as higher temperature-time combinations have been used in other studies, and in the use of reconstituted powder instead of fresh milk. Furthermore, the peak areas for $1 \times$ and $2 \times$ concentrated milk were not significantly affected by heating treatment (Figure $1 \mathrm{C}$ and $1 \mathrm{D})$. However, we did observe a statistically significant difference in the $4 \times$ milk concentrated by UF with heating. At this concentration, several different biochemical changes may have occurred during heating of $4 \times$ UF milk (e.g., whey protein denaturation, formation of heat-induced complexes, Ca binding, and modification of the structure and composition of micellar Ca phosphate) to cause the change in the buffering capacity area (Gaucheron et al., 1996; Guyomarc'h et al., 2003).

Figure 2 illustrates the differences in buffering capacity between retentates concentrated by UF or UF combined with DF. In general, at both concentrations, the maximum buffering peak at $\mathrm{pH} 5$ was significantly higher for UF concentrates compared with DF concentrates. No further $\mathrm{pH}$ shift was noted in the curves. These results suggest that some CCP is solubilized from the casein micelles during DF, confirming recent findings (Alexander et al., 2011). It is important to note that earlier studies have shown that dialysis of milk against water (i.e., a change in the ionic composition of the serum phase) while removing free $\mathrm{Ca}$ and other ions from the serum phase causes dissociation of caseins due to the loss of CCP (Abd El Salam et al., 1982; McSweeney and Fox, 2009). It is therefore possible that the process of DF during membrane filtration may cause some disruption of the micellar structure.

As shown for UF milk (Figure 1) and DF milk (Figure 2), no significant differences occurred in buffering capacity after heat treatment of the concentrates, further supporting the conclusion that heating milk at $80^{\circ} \mathrm{C}$ for 15 min did not perturb the CCP equilibrium of the casein micelles.
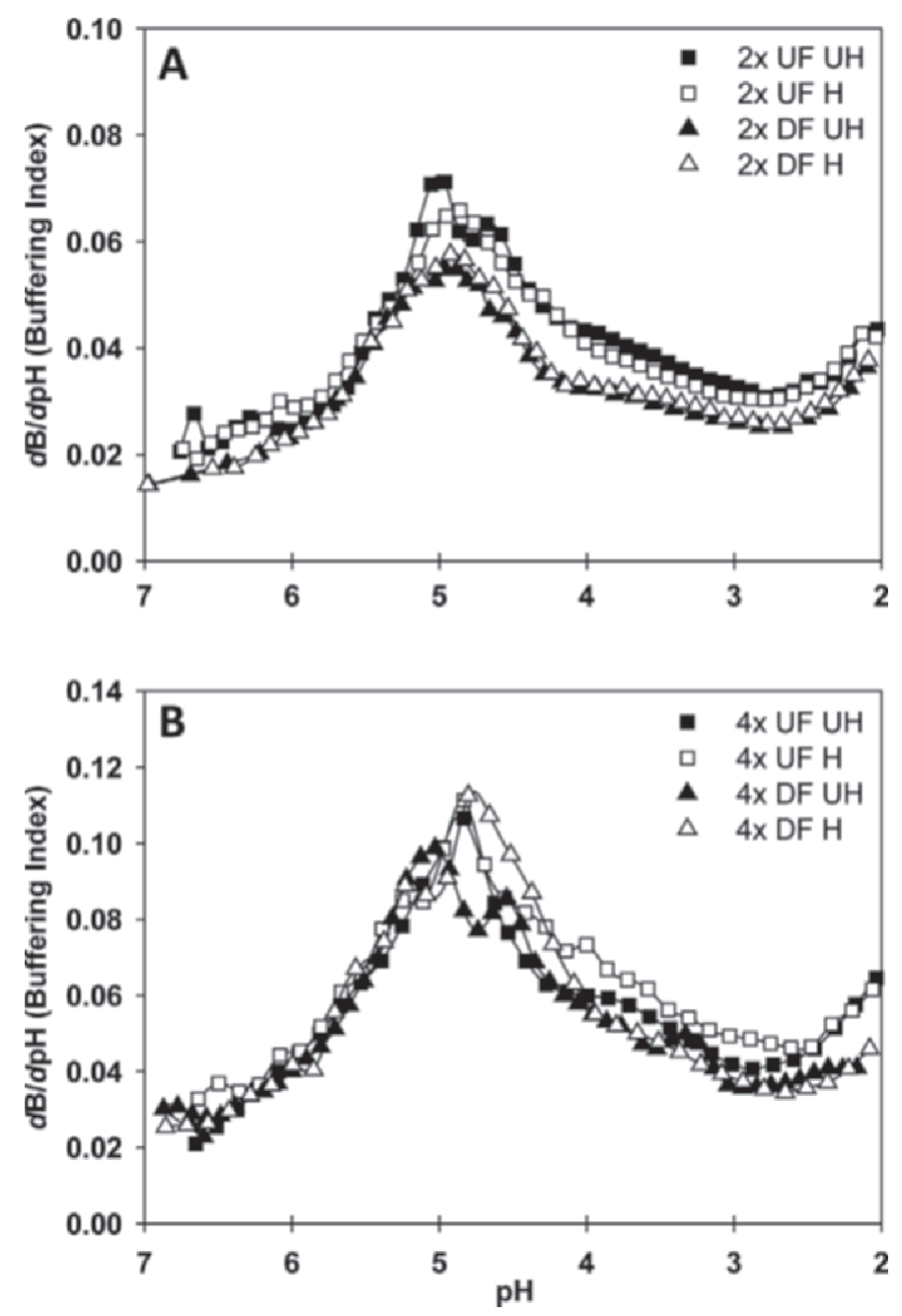

Figure 2. Buffering capacity (titration to $\mathrm{pH} 2$ ) for milk concentrated $2 \times(\mathrm{A})$ and $4 \times(\mathrm{B})$ by UF (squares) and diafiltration (DF; triangles). Unheated (UH; solid symbols) and heated samples (H; open symbols) are shown. Curves are representative of 3 replicate samples. 


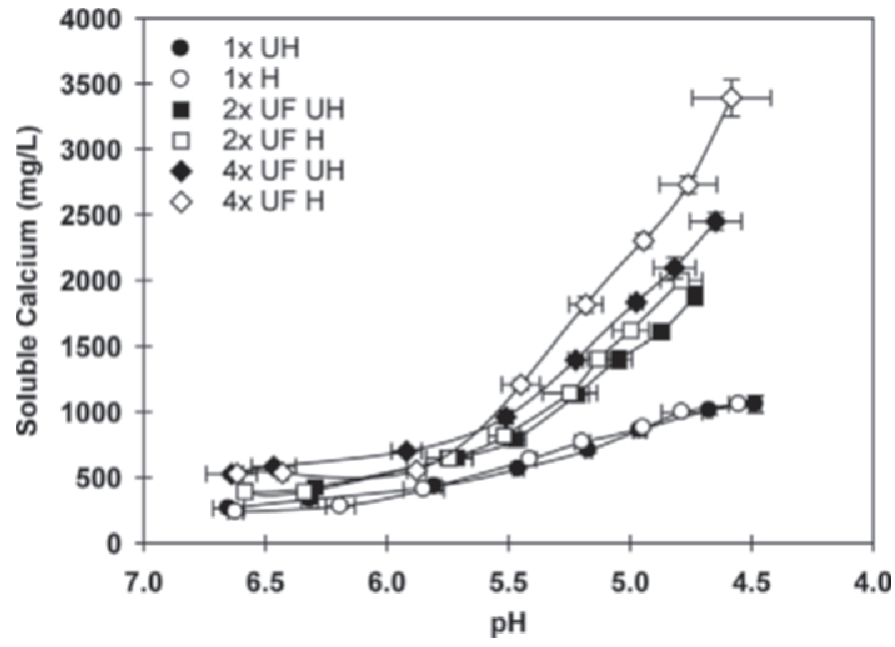

Figure 3. Amount of $\mathrm{Ca}$ recovered in the centrifugal supernatant of $1 \times$ control (circles), $2 \times \mathrm{UF}$ (squares), $4 \times \mathrm{UF}$ (diamonds), for unheated (UH; solid symbols) and heated (H; open symbols) samples, as a function of $\mathrm{pH}$. Values are the average of 2 independent experiments, and bars represent standard deviation.

\section{Acid-Induced Solubilization of Calcium}

To follow the details of the solubilization of Ca during acidification in the UF and DF samples, the amount of $\mathrm{Ca}$ present in the nonsedimentable fraction was measured during acidification with GDL. It is known that charge neutralization occurs during acidification along with gradual solubilization of CCP from the interior of the casein micelles (Dalgleish and Law, 1988; Le Graët and Gaucheron, 1999).

The amount of $\mathrm{Ca}$ recovered in the centrifugal supernatant for $1 \times$ (control) and $2 \times$ and $4 \times$ UF milks (unheated and heated) is shown in Figure 3. In agreement with previous reports on reconstituted casein micelles (Le Graët and Gaucheron, 1999), the solubilization of colloidal Ca occurred continuously during acidification. Solubilization increased around $\mathrm{pH} 5.5$ and, in the case of $1 \times$ milk, it seemed to reach a plateau at $\mathrm{pH} 4.6$. In general, this behavior was similar in all samples; however, in concentrated samples, a lag phase was detected before the concentration of $\mathrm{Ca}$ in the supernatant started to increase around $\mathrm{pH} 5.8$. After $\mathrm{pH} 5.5$, there was a higher concentration of $\mathrm{Ca}$ in the nonsedimentable fraction (Figure 3) due to the higher volume fraction of casein present in $2 \times$ and $4 \times$ concentrated milks compared with control milk.

Figure 3 also shows the effect of heat treatment of concentrated milk on the release of $\mathrm{Ca}$ with acidification. Heating causes denaturation of whey proteins and formation of complexes of whey proteins with casein micelles, soluble whey proteins, or $\kappa$-casein aggregates (Guyomarc'h et al., 2003; Anema, 2008, 2009). For con- trol milk, the behavior of heated samples was similar to that of unheated samples. In concentrated milk, we observed no differences at $\mathrm{pH}>5.5$ with heating. In addition, no significant differences were noted for milk concentrated $2 \times$. On the other hand, more Ca was released at $\mathrm{pH}<5.5$ in heated $4 \times$ milk than in unheated $4 \times$ milk. These observations suggest that heating has a significant effect on the structural arrangements of casein micelles concentrated to high volume fractions by UF, and that the higher release is attributable to a combination of heat-induced complexes and casein micelles with $\mathrm{pH}$.

Figure 4 illustrates the percentage of $\mathrm{Ca}$ solubilized as a function of casein concentration for the UF milk samples, at $4 \mathrm{pH}$ values between 6 and 4.6; acidification was conducted using GDL. The total Ca solubilized at various $\mathrm{pH}$ values was proportional to the amount of caseins present (Figure 4). However, at $\mathrm{pH}$ 4.6, only about $88 \%$ of the total Ca was solubilized in heated $4 \times$ UF milk, and this amount was significantly lower than for $1 \times$ milk, and significantly higher than the amount measured in unheated $4 \times \mathrm{UF}$.

In addition to studying the effect of concentration, the present work also determined possible differences in Ca release during acidification in milk concentrated by $\mathrm{DF}$ and the effect of heating at $80^{\circ} \mathrm{C}$ for $15 \mathrm{~min}$. No information is available on the effect of DF and UF on Ca release. Figure 5 compares the amount of $\mathrm{Ca}$ released in the nonsedimentable fraction as a function of $\mathrm{pH}$ for milk concentrated by UF or DF. The UF and DF samples showed similar trends, both for $2 \times$ and

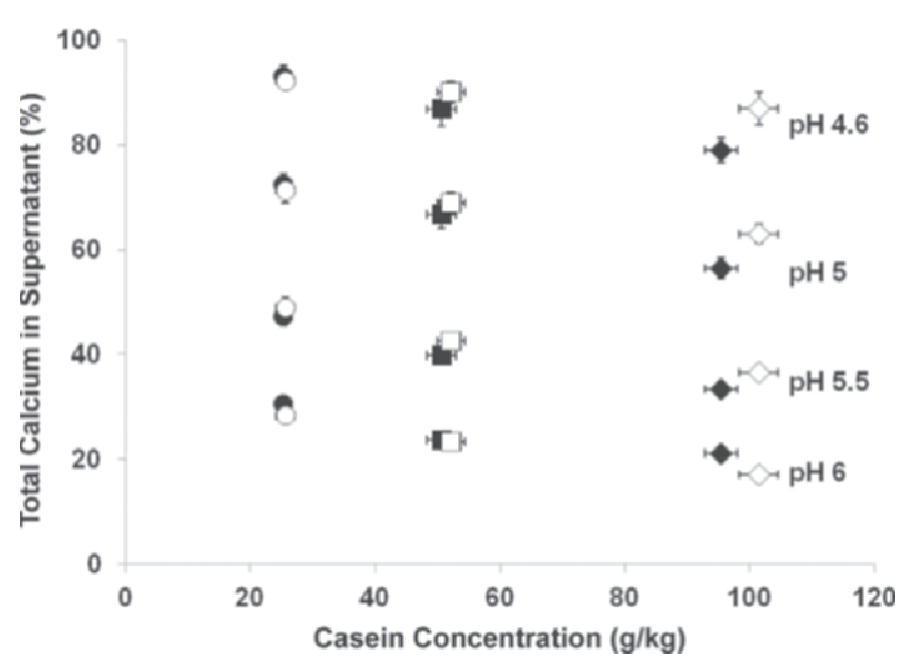

Figure 4. Amount of $\mathrm{Ca}$ recovered in the nonsedimentable fraction after centrifugation of $1 \times$ control (circles), $2 \times$ UF (squares), $4 \times$ UF (diamonds), for unheated (solid symbols) and heated (open symbols) samples, as a function of casein concentration, measured at 4 $\mathrm{pH}$ values $(6.0,5.5,5$, and 4.6). Results are averages of 2 separate experiments. 

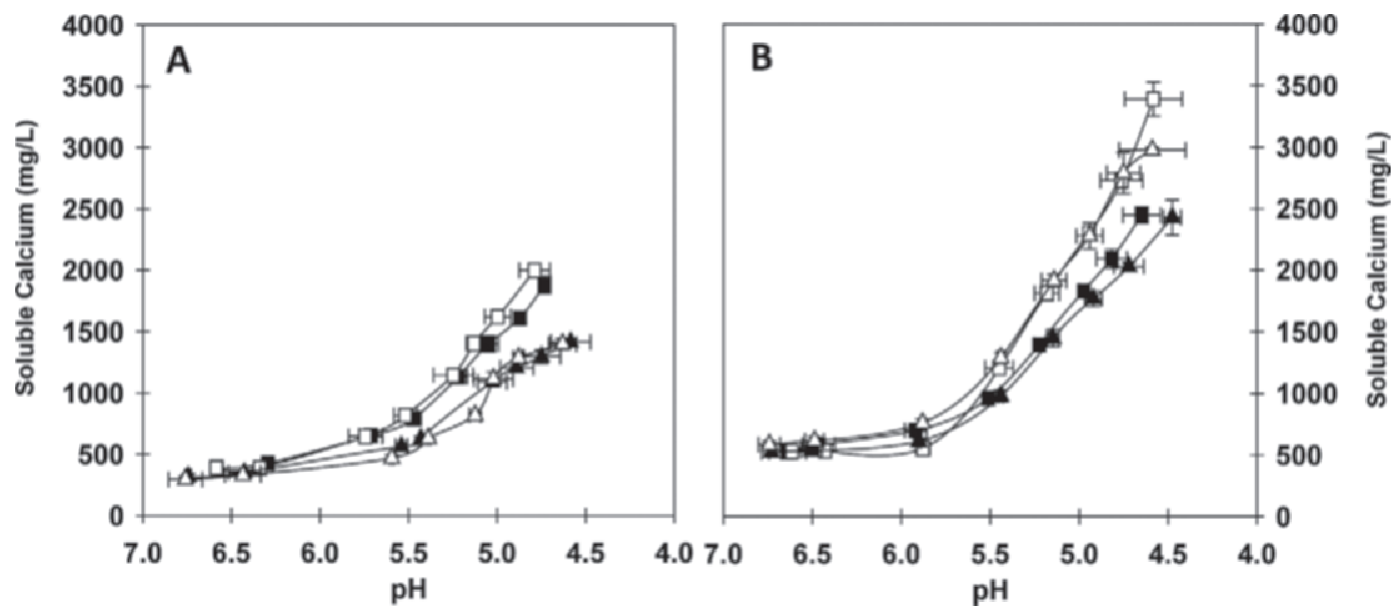

Figure 5. Amount of Ca recovered in the centrifugal supernatant of $2 \times(\mathrm{A})$ and $4 \times(\mathrm{B})$ concentrated milk as a function of pH. Milk was concentrated by UF (squares) and diafiltration (DF; triangles). Results show unheated (UH; solid symbols) and heated (H; open symbols) samples. Values are the average of 2 independent experiments, and bars represent standard deviations.

$4 \times$ milks; however, in $2 \times$ milk, there was significantly less $\mathrm{Ca}$ in DF milk compared with UF milk (Figure $5 \mathrm{~A})$. This behavior was not noted for milk concentrated $4 \times$ (Figure 5B). These observations are in line with the buffering capacity findings (Figures 1 and 2): at high concentration rates, UF also causes some changes to the CCP equilibrium, even without the addition of water during DF.

Heat treatment did not seem to affect the release of Ca from $2 \times \mathrm{UF}$ and DF milks (Figure 5A), but it showed significant differences in $4 \times \mathrm{UF}$ and $\mathrm{DF}$ samples: a greater amount of $\mathrm{Ca}$ was recovered in the centrifugal supernatants after heating (Figure 5B), much in agreement with the results for UF retentates (Figure 3).

Colloidal $\mathrm{Ca}$ phosphate is in dynamic equilibrium with the mineral components in the soluble phase (Holt et al., 1998; Holt, 2004). It has been previously hypothesized that because the milk is already saturated with $\mathrm{Ca}$ phosphate, a considerable proportion of soluble $\mathrm{Ca}$ and phosphate may be transferred into the colloidal state during the heating of concentrated milk (Anema, 2009). The amount of insoluble Ca related to the amount of CCP adjusted for the amount casein in the samples is shown in Figure 6 as a function of concentration of protein. Figure $6 \mathrm{~A}$ shows the values for all treatments at $\mathrm{pH} 5.0$, whereas Figure $6 \mathrm{~B}$ shows values at natural $\mathrm{pH}$. In Figure $6 \mathrm{~A}$, the amount of CCP per casein remained constant with protein concentration by UF at $\mathrm{pH} 5.0$, which is about $0.35 \pm 0.03 \mathrm{mM} / 100$ $\mathrm{g}$ of casein. These concentrations were significantly higher than those of DF samples. However, the amount of CCP present per casein decreased significantly with membrane filtration and was significantly lower for DF samples compared with UF samples (Figure 6B). The amount appeared to reach a plateau around $0.72 \pm 0.03$ for UF and $0.61 \pm 0.02$ for DF milk at $2 \times U F$, values significantly lower than those for UF and DF at $4 \times$ SM. We conclude that UF and DF have a significant effect on the structure of casein micelles, causing losses of colloidal Ca that may be reflected in a higher release of soluble caseins at natural $\mathrm{pH}$.

\section{CONCLUSIONS}

Buffering capacity and Ca release during acidification depend on the protein concentration, but not proportionally, particularly at volume fractions $>2 \times$. The shear and mixing occurring during membrane filtration might cause modifications to the casein micelles and serum environment. We observed clear differences in the dynamics of casein micelles concentrated by DF compared with UF, in spite of the similarities in protein concentration. However, this differentiation depends on the protein concentration. At relatively low concentrations, buffering capacity was lower and the amount of solubilized Ca was less in the DF milk than in the UF milk. No significant difference in buffering capacity and $\mathrm{Ca}$ release were observed in DF or UF milk at $4 \times$ volume fractions. During DF, dilution of the serum phase with water further affects the integrity of casein micelles, resulting in losses of colloidal Ca and compositional changes in the serum. Furthermore, heating milk at $80^{\circ} \mathrm{C}$ for 15 min did not show a significant effect on the distribution of $\mathrm{Ca}$ and integrity of casein micelles; however, at high protein concentrations $(4 \times)$, more $\mathrm{Ca}$ was solubilized, possibly because of differences in the whey protein aggregates present. These results have 


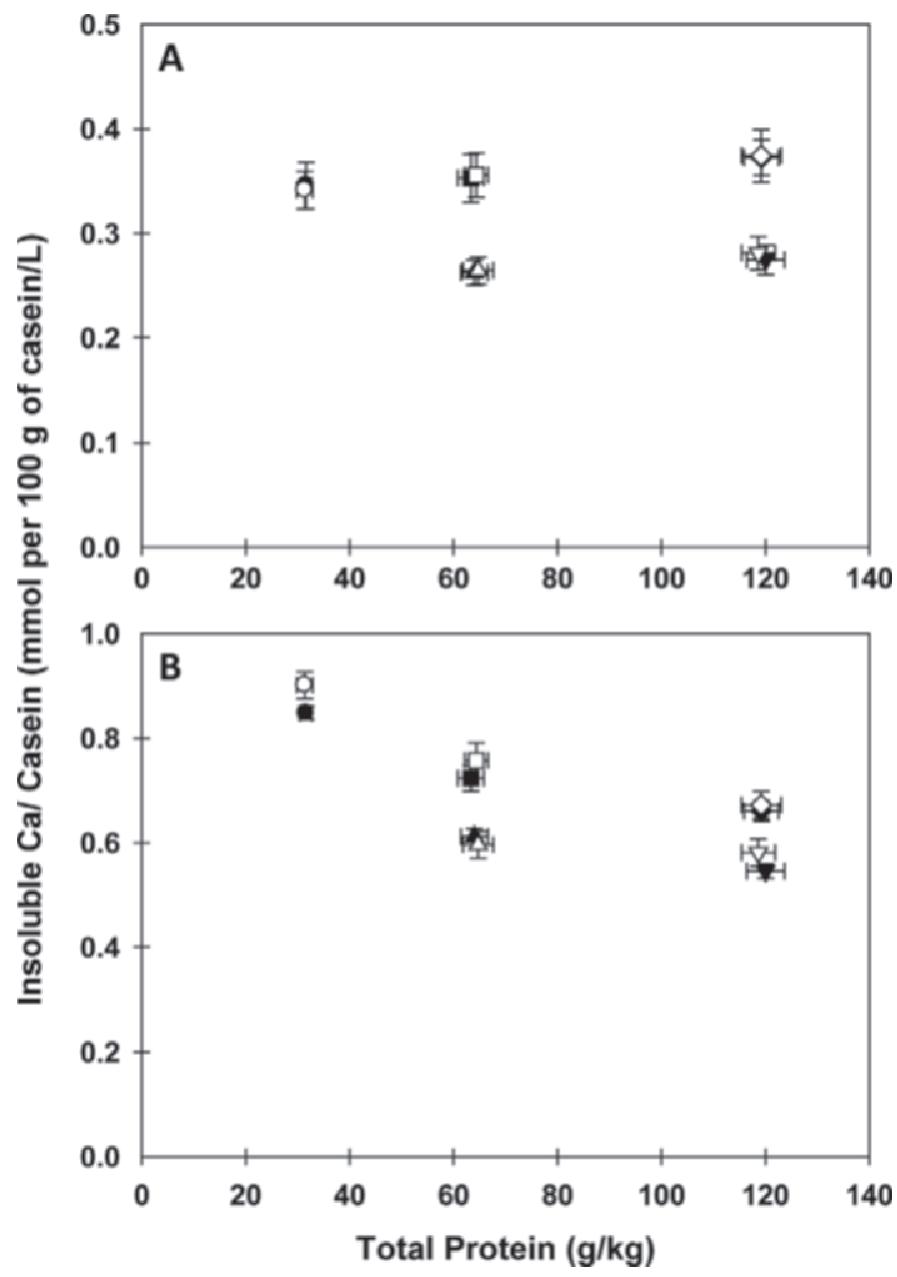

Figure 6. Amount of insoluble Ca divided by the amount of casein present in the milk as a function of protein concentration in the samples: $1 \times$ control (circle), $2 \times \mathrm{UF}$ (square), $4 \times \mathrm{UF}$ (diamond) and $2 \times$ diafiltration (DF; triangle), $4 \times \mathrm{DF}$ (down triangle), unheated (UH; solid) and heated (H; open), at pH 5.0 (A) and natural pH (B).

important implications in the utilization of retentates and milk concentrates for processing in yogurt and cheese-making operations.

\section{REFERENCES}

Abd El Salam, M. H., S. El Shibiny, H. A. El Alamy, and N. Mehanna. 1982. Ultrafiltration of buffalo milk. 1. Some properties of skim milk retentate. Asian J. Dairy Res. 1:35-40.

Alexander, M., M. P. Nieh, M. A. Ferrer, and M. Corredig. 2011. Changes in the calcium cluster distribution of ultrafiltered and diafiltered fresh skim milk as observed by small angle neutron scattering. J. Dairy Res. 78:349-356.

Anema, S. G. 2008. On heating milk, the dissociation of $\kappa$-casein from the casein micelles can precede interactions with the denatured whey proteins. J. Dairy Res. 75:415-421.

Anema, S. G. 2009. Effect of milk solids concentration on the $\mathrm{pH}$, soluble calcium and soluble phosphate levels of milk during heating. Dairy Sci. Technol. 89:501-510.
Brule, G., J. L. Maubois, and J. Fauquant. 1974. Contents of mineral elements in products from ultrafiltered milk. Lait 54:600-615.

Dalgleish, D. G., and A. J. R. Law. 1988. pH-induced dissociation of casein micelles. I. Analysis of liberated caseins. J. Dairy Res. 55:529-538.

Dalgleish, D. G., E. Verespej, M. Alexander, and M. Corredig. 2005. The ultrasonic properties of skim milk related to the release of calcium from casein micelles during acidification. Int. Dairy J. 15:1105-1112.

Davies, D. T., and J. C. D. White. 1960. The use of ultrafiltration and dialysis in isolating the aqueous phase of milk and in determining the partition of milk constituents between the aqueous and disperse phases. J. Dairy Res. 27:171-190.

DeKruif, C. G. 1998. Supra-aggregates of casein micelles as a prelude to coagulation. J. Dairy Sci. 81:3019-3028.

Downey, W. K., and R. F. Murphy. 1970. The temperature-dependent dissociation of $\beta$-casein from bovine casein micelles and complexes. J. Dairy Res. 37:361-372.

Ferrer, M., M. Alexander, and M. Corredig. 2011. Does ultrafiltration have a lasting effect on the physico-chemical properties of the casein micelles? Dairy Sci. Technol. 91:151-170.

Gaucheron, F., Y. Le Graet, M. Piot, and E. Boyaval. 1996. Determination of anions of milk by ion chromatography. Lait 76:433-443.

Guyomarc'h, F., A. J. R. Law, and D. G. Dalgleish. 2003. Formation of soluble and micelle-bound protein aggregates in heated milk. J. Agric. Food Chem. 51:4652-4660.

Hardy, E. E., D. Muir, M. A. W. Sweetsur, and I. G. West. 1984 Changes of calcium phosphate partition and heat stability during manufacture of sterilized concentrated milk. J. Dairy Sci. 67:1666-1673.

Holt, C. 2004. An equilibrium thermodynamic model of the sequestration of calcium phosphate by casein micelles and its application to the calculation of the partition of salts in milk. Eur. Biophys. J. 33:421-434.

Holt, C., P. A. Timmins, N. Errington, and J. Leaver. 1998. A coreshell model of calcium phosphate nanoclusters stabilized by $\beta$-casein phosphopeptides, derived from sedimentation equilibrium and small-angle X-ray and neutron-scattering measurements. Eur. J. Biochem. 252:73-78.

Law, A. J. R., and J. Leaver. 1998. Effects of acidification and storage of milk on dissociation of bovine casein micelles. J. Agric. Food Chem. 46:5008-5016.

Le Graët, Y., and F. Gaucheron. 1999. pH-induced solubilization of minerals from casein micelles: Influence of casein concentration and ionic strength. J. Dairy Res. 66:215-224.

Lucey, J. A., and P. F. Fox. 1993. Importance of calcium and phosphate in cheese manufacture: A review. J. Dairy Sci. 76:1714-1724.

Lucey, J. A., C. Gorry, and P. F. Fox. 1993a. Acid-base buffering properties of heated milk. Milchwissenschaft 48:438-441.

Lucey, J. A., C. Gorry, B. O'Kennedy, M. Kalab, R. Tan-Kinita, and P. F. Fox. 1996. Effect of acidification and neutralization of milk on some physico-chemical properties of casein micelles. Int. Dairy J. 6:257-272.

Lucey, J. A., B. Hauth, C. Gorry, and P. F. Fox. 1993b. The acid-base buffering properties of milk. Milchwissenschaft 48:268-272.

Marchin, S., J. L. Putaux, F. Pignon, and J. Léonil. 2007. Effects of the environmental factors on the casein micelle structure studied by cryo transmission electron microscopy and small-angle $\mathrm{x}$ ray scattering/ultrasmall-angle x-ray scattering. J. Chem. Phys. 126:045101. http://dx.doi.org/10.1063/1.2409933.

McSweeney, P. L. H., and P. F. Fox. 2009. Lactose, water, salts, and minor constituents. Pages 10-25 in Advanced Dairy Chemistry. Vol. 3. 3rd ed. Springer Science, New York, NY.

Mistry, V. V., and F. V. Kosikowski. 1985. Growth of lactic acid bacteria in highly concentrated ultrafiltered skim milk potentates. J. Dairy Sci. 68:2536-2543.

Mistry, V. V., and J. J. Maubois. 2004. Application of membrane separation technology to cheese production. Pages 261-286 in Cheese: Chemistry, Physics and Microbiology. Vol. 1. P. F. Fox, P. L. H. 
McSweeney, T. M. Cogan, and T. P. Guinee, ed. Elsevier Academic Press, London, UK.

Pierre, A., and G. Brule. 1981. Mineral and protein equilibria between the colloidal and soluble phases of milk at low temperature. J. Dairy Res. 48:417-428.

Pouliot, Y., M. Boulet, and P. Paquin. 1989. Observations on the heat-induced salt balance changes in milk I. Effect of heating time between 4 and $90^{\circ} \mathrm{C}$. J. Dairy Res. 56:185-192.

Rahimi-Yazdi, S., M. A. Ferrer, and M. Corredig. 2010. Nonsuppressed ion chromatographic determination of total calcium in milk. J. Dairy Sci. 93:1788-1793.
Rose, D., and H. Tessier. 1959. Composition of ultrafiltrates from milk heated at 80 to $230{ }^{\circ} \mathrm{F}$ in relation to heat stability. J. Dairy Sci. 42:969-980.

Salaün, F., B. Mietton, and F. Gaucheron. 2005. Buffering capacity of dairy products. Int. Dairy J. 15:95-109.

Srilaorkul, S., L. Ozimek, F. Wolfe, and J. Dziuba. 1989. The effect of ultrafiltration on physicochemical properties of retentate. Can. Inst. Food Sci. Technol. J. 22:56-62.

St-Gelais, D., S. Haché, and M. Gros-Louis. 1992. Combined effects of temperature, acidification, and diafiltration on composition of skim milk retentate and permeate. J. Dairy Sci. 75:1167-1172. 